\title{
Influence of Load-bearing Structure on Size of Bonded Facade Cladding
}

\author{
Pavel Liška ${ }^{1, *}$, Barbora Nečasová $^{1}$, and Jiř́ Šlanhof ${ }^{1}$ \\ ${ }^{1}$ Brno University of Technology, Faculty of Civil Engineering, Veveři 331/95, Brno 602 00, Czech \\ Republic
}

\begin{abstract}
Architecture has been an integral part of our lives ever since people first existed. Structures are required by both investors and society to have what is considered a highly modern appearance while maintaining elements of a long service life. To meet such requirements, it is necessary to use modern technologies and materials. Bonded joints represent one of the options. Unlike with mechanical joints, it is possible to use bonded joints to anchor large format cladding panels to bearing substructures of various shapes and sizes. The design is simple, but very technically demanding to implement. One of the factors which have an impact on both the design and its implementation is the bearing substructure itself. As part of a research project, a load bearing substructure made from wood and aluminium alloy was tested. The test results prove that the mechanical properties of the materials used, especially their thermal and moisture expansion, directly influence the size of the cladding. In the case of a bearing substructure made from wood, the cladding may be larger by several percentage points than in the case of a bearing substructure made from aluminium alloy.
\end{abstract}

\section{Introduction}

The character of the landscape which surrounds us is shaped not only by natural processes but also the buildings we have created within it. An unprecedented degree of emphasis is placed on architecture today. Not only investors but also society demand that buildings exhibit what is considered a modern appearance without sacrificing any of the long service life that is desired of them. In order to fulfil these requirements, modern technologies as well as materials must be used. Ceramic cladding has always had an irreplaceable position in the building industry and this situation remains unchanged even today [1-3]. The range of utility properties and advantages of ceramic cladding have stayed the same but aesthetic requirements have shifted over time. At present, a significantly progressive growth in the popularity of large-format cladding elements can be observed. Large-format cladding with a minimum of joints has become unexpectedly popular not only with architects but also with the wider public. In the case of ventilated facades for buildings, the anchoring of large-format cladding to load-bearing substructure usually takes place mechanically. Stress concentration occurs at the locations of mechanical joints, lowering fatigue strength [4-5]. Apart from this,

\footnotetext{
${ }^{*}$ Corresponding author: liska.p@,fce.vutbr.cz
} 
scratches, notches and other flaws occur at these locations more frequently during the installation of screws. This can subsequently make the penetration of local pollution into the cladding material easier. When adhesives are used, these deficiencies can be prevented. Even though the anchorage of cladding to a load-bearing substructure using adhesives is not covered by existing legislation [6-7], the increasing requirements concerning the combination of the materials used has caused bonding to become an ever more widely used anchorage technique [8]. An individual approach has to be taken to the design and realization of any bonded facade system. This approach is influenced by such factors as the position (locality) of the structure or the facade, the orientation of the facade to the points of the compass, climatic conditions, the selected type of material, etc.

Research was performed concerning the influence of the material chosen to construct the load-bearing substructure for a bonded facade on the final size of the cladding material with regard to the bonding system used. This research is the source of the results and conclusions presented in this contribution.

\section{Methodology}

\subsection{Materials}

The selection of the cladding material to be used is usually carried out by the investor that commissioned the work. This step should always be taken before considering the use of bonded facade systems because material characteristics such as mechanical, physical and chemical properties should already be known before the selection of a specific type of facade adhesive and the material of the load-bearing structure. An unsuitable combination of selected materials can cause a considerable decrease in the lifespan of the whole facade system. It is therefore necessary to pay increased attention to the selection of specific glued components of the facade as early as during the design stage. Many people assume that the choice of material for the load-bearing substructure is only a formality. However, the loadbearing substructure has a significant impact on the final size of the cladding material and, in many cases, also on the selection of the bonding system. It has been determined [9] that in cases when the temperature and humidity properties of the load-bearing substructure and cladding material are significantly different, the choice of a suitable bonding system compensates for their dissimilar properties.

Four bonding systems were selected for the execution of experimental measurements. The first three systems presented in Table 1 were intended to be used directly on bonded facades. The last bonding system mentioned, Type IV, is intended only for general construction bonding. The chosen systems include examples of both one-component polyurethane adhesives and one-component MS polymers.

Table 1. Basic material properties of adhesives as stated by their producers [10].

\begin{tabular}{|l|c|c|c|}
\hline \multicolumn{1}{|c|}{ Adhesive System } & $\begin{array}{c}\text { Tensile Strength } \\
{[\mathbf{M P a}]}\end{array}$ & $\begin{array}{c}\text { Shear Strength } \\
{[\mathbf{M P a}]}\end{array}$ & Material Base \\
\hline Type I & 4.0 & 2.5 & Polyurethane \\
\hline Type II & 9.0 & 5.5 & Polyurethane \\
\hline Type III & 1.2 & 1.6 & MS - Polymer \\
\hline Type IV & 3.5 & 3.0 & MS - Polymer \\
\hline
\end{tabular}


For the purposes of the presented research, the cladding material employed was largeformat ceramic cladding, which is suitable for use on ventilated building facades due to its properties, see Table 2. During the research, a load-bearing substructure made from aluminium alloy was tested along with a timber substructure (spruce, strength class C24). The basic technical parameters are shown in Table 3.

Table 2. Selected material properties of the tested ceramic facade cladding [11].

\begin{tabular}{|l|c|}
\hline Properties & Average Values \\
\hline Bulk density & $2800 \mathrm{~kg} \cdot \mathrm{m}^{-3}$ \\
\hline Thermal expansion coefficient & $6.0 \cdot 10^{-6} \cdot \mathrm{K}^{-1}$ \\
\hline Expansion when air humidity changes from $35 \%$ to $95 \%$ & $0.000 \mathrm{~mm} \cdot \mathrm{m}^{-1}$ \\
\hline Maximum cladding dimensions (according to the producer) & $3000 \times 1000 \mathrm{~mm}$ \\
\hline
\end{tabular}

Table 3. Selected material properties of the tested load-bearing substructures [12-13].

\begin{tabular}{|c|c|c|}
\hline \multirow{2}{*}{$\begin{array}{l}\text { Properties/Load-bearing } \\
\text { Substructure }\end{array}$} & \multicolumn{2}{|c|}{ Average Values } \\
\hline & Aluminium Alloy & $\begin{array}{c}\text { Wood } \\
\text { (Spruce C24) } \\
\end{array}$ \\
\hline Tensile strength & $65-470 \mathrm{MPa}$ & $\begin{array}{l}14 \mathrm{MPa} \text { (parallel with the fibres) } \\
0.4 \mathrm{MPa} \text { (vertical to the fibres) }\end{array}$ \\
\hline Thermal expansion coefficient & $23 \cdot 10^{-6} \cdot \mathrm{K}^{-1}$ & $5 \cdot 10^{-6} \cdot \mathrm{K}^{-1}$ (parallel with the fibres) \\
\hline $\begin{array}{l}\text { Expansion when air humidity } \\
\text { changes from } 35 \% \text { to } 95 \%\end{array}$ & $0.000 \mathrm{~mm} \cdot \mathrm{m}^{-1}$ & $0.500 \mathrm{~mm} \cdot \mathrm{m}^{-1}$ \\
\hline
\end{tabular}

\subsection{Methods}

Experimental testing of the suitability of the selected adhesives in combination with ceramic cladding and the material chosen for the load-bearing substructure for use with ventilated facades was carried out based on the declaration of conformity [14].

In order to achieve the aims defined above, the adhesion of the surface finish of the building structure had to be determined first, i.e. the adhesion of the cladding to the base via the adhesive. The tests basically involve the recording of the maximum force which was able to tear off a pre-defined area of the tested surface finish from the base using a normal force, as defined by the ČSN 732577 standard [15]. The second test method imposed upon the test specimens consisted in the determination of the strength of a bonded assembly in shear during tensile loading according to the procedure defined in the ČSN EN 1465 standard [16]. The production, conditioning and testing of the samples from which the maximum force during the adhesion failure and shear strength of a bonded joint was determined together with displacement have already been described by the authors of this article in previous publications [17-18].

\subsubsection{Determination of the tensile stress in the bonded joint}

Adhesion and shear strength characterize the mechanical properties of a glued joint and their determination is essential for the performance of further calculations. The tensile 
strength/adhesion of the surface finish to the base and the determination of the shear strength during tensile stress are calculated using formula (1).

$$
\sigma_{a d h}(\tau)=\frac{F_{\max }}{A_{e f}}
$$

where

$\sigma_{\text {adh }}(\tau)$ adhesion / shear strength of the surface finish to the base under tensile stress, in $\mathrm{MPa}$

$\mathrm{F}_{\max }$ the maximum force required for the sample debonding, in $\mathrm{N}$

$\mathrm{A}_{\mathrm{ef}}$ the effective surface area of the bonded joint, in $\mathrm{mm}^{2}$

\subsubsection{Determination of the stiffness of the supports}

In order to calculate the size of the cladding material, the stiffness of the supports (i.e. the bonding system) needs to be calculated both in tension and in shear according to formula (2). The bonding system is capable of eliminating the tension from the mutual shifting of facade elements within its mass.

$$
k=\frac{\frac{F_{\max }}{A_{e f}}}{\frac{\Delta l}{l_{o}}}=\frac{\sigma_{a d h}(\tau)}{\varepsilon}=E
$$

where

$\mathrm{k}$ the stiffness of the support in tension, in $\mathrm{N} / \mathrm{mm}^{2}$

E Young's elasticity modulus, in $\mathrm{N} / \mathrm{mm}^{2}$

$\mathrm{F}_{\text {max }}$ the maximum force required for the sample debonding, in $\mathrm{N}$

$\mathrm{A}_{\mathrm{ef}}$ the effective surface area of the bonded joint, in $\mathrm{mm}^{2}$

$\Delta l \quad$ the difference between the length of the bonded joint at failure and its initial length, in mm

$1_{0}$ the initial length of the bonded/cemented joint, in $\mathrm{mm}$

$\sigma_{\text {adh }}(\tau)$ the adhesion (shear strength) of the bonded set under tensile loading, in $\mathrm{N} / \mathrm{mm}^{2}$

$\varepsilon \quad$ relative elongation, a dimensionless variable

\subsubsection{Determination of the load applied to the facade system}

The verification of the load-bearing capacity of the adhesive is calculated for the effects of wind according to formula (3), and the self-weight of the cladding and the thermal and moisture expansion of the cladding and load-bearing substructure, according to formula (4). The calculation and combination of individual loading states was carried out in accordance with the ČSN EN 1990 standard [19] (i.e. the same procedure as defined by Eurocode 1), a detailed description of the procedure for determining the magnitude of the load has already been presented by the authors [18].

The calculation considers the wind load to be $482.3 \mathrm{~N} \cdot \mathrm{m}^{-2}$. This corresponds to the wind strength present in a Category II wind exposure area in the Czech Republic. The calculation was carried out for a $12 \mathrm{~m}$ high structure. This is the maximum permitted height of a structure when the anchoring method of bonding to the load-bearing substructure is used. This requirement is related to issues connected with the fire safety of the facade and does not concern the static capabilities of the system. 


$$
\frac{R_{z}}{\sigma} \leq 1
$$

where

$\sigma \quad$ adhesion/tensile strength (experimental measurements), in $\mathrm{MPa}$

$\mathrm{R}_{\mathrm{z}} \quad$ stress caused by wind effects (Nexis32 software), in MPa

The thermal and moisture expansion of the cladding is considered in the calculation along with the self weight of the cladding. Furthermore, the thermal expansion of the load-bearing substructure is also taken into account if it is made of aluminium alloy, whereas if it is made of wood, its thermal and moisture expansion is considered.

$$
\sqrt{\left(\frac{R_{x}}{\tau}\right)^{2}+\left(\frac{R_{y}}{\tau}\right)^{2}} \leq 1
$$

where

$\tau \quad$ shear strength (experimental measurements), in $\mathrm{MPa}$

$R_{x}$ and $R_{y}$ stress caused by the self weight and the thermal and moisture expansion of the cladding and the load-bearing substructure (Nexis32), in MPa

\section{Results and discussion}

The tensile stress in the bonded joint was determined according to formula (1). Results presented in Tables 4 and 5 show the lowest $5^{\text {th }}$ percentile of the adhesion and shear stress values obtained for 18 test specimens for each adhesive and test. The best results were achieved in the case of the Type II bonding system while the worst were obtained for the Type I system.

Table 4. The lowest $5^{\text {th }}$ percentile of the adhesion and shear stress values for an aluminium alloy load-bearing substructure.

\begin{tabular}{|l|c|c|c|c|}
\hline \multicolumn{1}{|c|}{ Adhesive system } & $\begin{array}{c}\text { Adhesion } \boldsymbol{\sigma} \\
{[\mathbf{M P a}]}\end{array}$ & $\begin{array}{c}\text { Elongation } \\
{[\mathbf{m m}]}\end{array}$ & $\begin{array}{c}\text { Shear Stress } \\
{[\mathbf{M P a}]}\end{array}$ & $\begin{array}{c}\text { Elongation } \\
{[\mathbf{m m}]}\end{array}$ \\
\hline Type I & 1.579 & 6.864 & 1.359 & 10.625 \\
\hline Type II & 2.268 & 3.616 & 5.550 & 11.003 \\
\hline Type III & 1.930 & 1.676 & 1.586 & 5.552 \\
\hline Type IV & 1.935 & 1.184 & 1.584 & 6.953 \\
\hline
\end{tabular}

Table 5. The lowest $5^{\text {th }}$ percentile of the adhesion and shear stress values for a timber load-bearing substructure.

\begin{tabular}{|l|c|c|c|c|}
\hline \multicolumn{1}{|c|}{ Adhesive system } & $\begin{array}{c}\text { Adhesion } \\
{[\mathbf{M P a}]}\end{array}$ & $\begin{array}{c}\text { Elongation } \\
{[\mathbf{m m}]}\end{array}$ & $\begin{array}{c}\text { Shear Stress } \mathbf{\tau} \\
{[\mathbf{M P a}]}\end{array}$ & $\begin{array}{c}\text { Elongation } \\
{[\mathbf{m m}]}\end{array}$ \\
\hline Type I & 1.083 & 4.723 & 1.351 & 10.821 \\
\hline Type II & 1.560 & 2.506 & 5.574 & 11.278 \\
\hline
\end{tabular}




\begin{tabular}{|l|c|c|c|c|}
\hline Type III & 1.299 & 1.120 & 1.592 & 5.662 \\
\hline Type IV & 1.340 & 0.875 & 1.601 & 6.787 \\
\hline
\end{tabular}

Moreover, the stiffness of the supports was determined. The results presented in Table 6 shows the highest $95^{\text {th }}$ percentile of the obtained support stiffness values. These values are included in calculations carried out using Nexis32 specialized software. The lower the stiffness of the adhesive, the greater is its elongation under the same force.

Table 6. Support stiffness values for load-bearing substructures made from aluminium alloy and wood.

\begin{tabular}{|l|c|c|c|c|}
\hline \multirow{2}{*}{$\begin{array}{c}\text { Adhesive System / } \\
\text { Supporting } \\
\text { Substructure }\end{array}$} & $\begin{array}{c}|c| \\
\text { Stiffness of } \\
\text { Support in } \\
\text { Tension } \\
{\left[\mathbf{N} / \mathbf{m m}^{2}\right]}\end{array}$ & $\begin{array}{c}\text { Stiffness of } \\
\text { Support in } \\
\text { Shear } \\
{\left[\mathbf{N} / \mathbf{m m}^{2}\right]}\end{array}$ & $\begin{array}{c}\text { Stiffness of } \\
\text { Support in } \\
\text { Tension } \\
{\left[\mathbf{N} / \mathbf{m m}^{2}\right]}\end{array}$ & $\begin{array}{c}\text { Stiffness of } \\
\text { Support in } \\
\text { Shear } \\
{\left[\mathbf{N} / \mathbf{m m}^{2}\right]}\end{array}$ \\
\hline Type I & 0.712 & 2.339 & 0.716 & 2.367 \\
\hline Type II & 2.456 & 6.845 & 2.384 & 6.763 \\
\hline Type III & 3.548 & 3.885 & 3.522 & 3.790 \\
\hline Type IV & 3.851 & 5.121 & 3.619 & 5.210 \\
\hline
\end{tabular}

The influence of individual loading states on the total stress in a bonded joint was determined and the expressions in percent of the influence of individual loading states on the total stress in a bonded joint for the two load-bearing substructures is shown in Table 7 and Table 8. The load-bearing substructure, which is firmly anchored to the base, has the greatest impact on the total stress. In the case of the aluminium alloy load-bearing substructure, the percentage is less than $82 \%$ on average for all bonding systems. In the case of the wooden load-bearing substructure, the percentage is $77 \%$.

Table 7. Expression of the influence of individual loading states on the total stress in a bonded joint for the aluminium alloy.

\begin{tabular}{|l|c|c|c|c|c|}
\hline $\begin{array}{c}\text { Adhesive system / } \\
\text { Load Condition }\end{array}$ & $\begin{array}{c}\text { Self-weight } \\
\text { of the } \\
\text { Cladding } \\
{[\%]}\end{array}$ & $\begin{array}{c}\text { Thermal } \\
\text { Expansion } \\
\text { of the } \\
\text { Cladding } \\
{[\%]}\end{array}$ & $\begin{array}{c}\text { Moisture } \\
\text { Expansion } \\
\text { of the } \\
\text { Cladding } \\
{[\%]}\end{array}$ & $\begin{array}{c}\text { Thermal } \\
\text { Expansion of } \\
\text { the } \\
\text { Substructure } \\
{[\%]}\end{array}$ & $\begin{array}{c}\text { Moisture } \\
\text { Expansion of } \\
\text { the } \\
\text { Substructure } \\
{[\%]}\end{array}$ \\
\hline Type I & 0.934 & 14.878 & 0.055 & 84.132 & 0 \\
\hline Type II & 0.453 & 20.107 & 0.074 & 79.365 & 0 \\
\hline Type III & 0.653 & 16.973 & 0.063 & 82.312 & 0 \\
\hline Type IV & 0.544 & 18.398 & 0.068 & 80.990 & 0 \\
\hline
\end{tabular}


Table 8. Expression of the influence of individual loading states on the total stress in a bonded joint for the wooden substructure.

\begin{tabular}{|l|c|c|c|c|c|}
\hline $\begin{array}{c}\text { Adhesive system / } \\
\text { Load Condition }\end{array}$ & $\begin{array}{c}\text { Self-weight } \\
\text { of the } \\
\text { Cladding } \\
{[\%]}\end{array}$ & $\begin{array}{c}\text { Thermal } \\
\text { Expansion } \\
\text { of the } \\
\text { Cladding } \\
{[\%]}\end{array}$ & $\begin{array}{c}\text { Moisture } \\
\text { Expansion } \\
\text { of the } \\
\text { Cladding } \\
{[\%]}\end{array}$ & $\begin{array}{c}\text { Thermal } \\
\text { Expansion of } \\
\text { the } \\
\text { Substructure } \\
{[\%]}\end{array}$ & $\begin{array}{c}\text { Moisture } \\
\text { Expansion of } \\
\text { the } \\
\text { Substructure } \\
{[\%]}\end{array}$ \\
\hline Type I & 1.212 & 19.530 & 0.072 & 26.395 & 52.790 \\
\hline Type II & 0.551 & 24.184 & 0.090 & 25.059 & 50.117 \\
\hline Type III & 0.837 & 21.260 & 0.079 & 25.941 & 51.883 \\
\hline Type IV & 0.662 & 22.753 & 0.084 & 25.500 & 51.001 \\
\hline
\end{tabular}

Table 9. Results of the calculations performed according to equations (3) and (4).

\begin{tabular}{|l|c|c|c|c|}
\hline \multirow{2}{*}{$\begin{array}{c}\text { Adhesive System / } \\
\text { Load-bearing } \\
\text { Substructure }\end{array}$} & \multicolumn{2}{|c|}{ Aluminium Alloy } & \multicolumn{2}{c|}{ Wood } \\
\cline { 2 - 5 } & Equation (3) & Equation (4) & Equation (3) & Equation (4) \\
\hline Type I & 0.021 & 0.349 & 0.031 & 0.234 \\
\hline Type II & 0.015 & 0.150 & 0.022 & 0.106 \\
\hline Type III & 0.018 & 0.403 & 0.027 & 0.272 \\
\hline Type IV & 0.018 & 0.106 & 0.026 & 0.077 \\
\hline
\end{tabular}

Table 9 shows the results of calculations performed according to equations (3) and (4). The best results are achieved in the case of the Type IV bonding system when both aluminium alloy and wood are used. It needs to be emphasized that this system is not intended for use with bonded facades. In contrast, the worst results occur when the Type III bonding system is used. The basic static calculation took the width of one panel to be $1000 \mathrm{~mm}$. For the purposes of the research project, the term "large-format ceramic cladding element" was defined as a planar ceramic cladding element of which at least one of the dimensions exceeds $1000 \mathrm{~mm}$. The calculated maximum dimensions of the cladding for the load-bearing substructure made from aluminium alloy as well as that made from wood are $1000 \times 3000$ $\mathrm{mm}$ for all of the tested bonding systems.

\section{Conclusions}

The bonding systems differ with regard to the elongation at which tearing occurs. If the bonding system is so stiff that it does not enable elongation, failure of the joint occurs either in the cladding or within the bonded joint itself, and it subsequently falls off. For this reason, the use of an adhesive with high stiffness is completely unsuitable for less resistant materials. To a certain degree, this fact can be minimized by using a smaller board format with which such great deformation does not occur. Cement bonded particleboard is a type of cladding with low resistance yet high thermal and moisture expansion. This cladding should not be combined with adhesives featuring high stiffness and a load-bearing substructure made from 
aluminium alloy. When cladding with high resistance and minimal thermal and moisture expansion is used, e.g. ceramic cladding, the use of a bonding system with high stiffness is completely problem-free.

The thermal expansion coefficient, which is $18 \cdot 10^{-6} \cdot \mathrm{K}^{-1}$ higher in the case of aluminium than in the case of wood, has an essential influence on the difference between the properties of load-bearing substructures made from such materials. On the other hand, wood is influenced by changes in the relative humidity of the air. This is a significant factor which compensates for the thermal expansion of aluminium to a large degree.

Cladding size has a significant effect on the strength of bonded joints in shear. As this system can only be used for structures with a maximum height of $12 \mathrm{~m}$, the requirements for joint adhesion are significantly lower than for shear strength.

This contribution was supported by the Czech Ministry of Industry and Trade under the TRIO programme No. FV20606 and Brno University of Technology under Grant No. FAST-S-17-4255.

\section{References}

1. N. Riley, Tile Art: A History of Decorative Ceramic Tiles (Magna Books, 1992)

2. Ceramic Society of Japan, Advanced Ceramic Technologie \& Products (Springer, 2012)

3. D. Watkin, A History of Western Architecture (Laurence King Publishing, 1986)

4. G. Krüger, R. Schneider, Otto-Graf-J. 10, 87-98 (1999)

5. Y. Ciupack, P. Hartmut, S. Manuel, I. Erdeniz, Steel Construction 7, 178-182 (2014)

6. IJ.J. van Straalen et. al., Int. J. Adhes. 18, 41 - 49 (1998)

7. H. Pasternak, Y. Ciupack, Int. J. Adhes. 53, 97-106 (2014)

8. M. Švábeník, Stavebnictvi3000, http://www.stavebnictvi3000.cz/clanky/skryte-lepenifasadnich-obkladu-sikatack-panel-system (January, 2018)

9. B. Nečasová, P. Liška, M. Novotný, Proceedia Eng., Submitted 2017-10-05

10. Technical documentation of relevant adhesive system

11. http://www.irisceramica.com (January, 2018)

12. https://www.alumeco.cz/technické-informace/údaje-o-hliníku/vlastnosti-hliníku?s=0 (January, 2018)

13. http://people.fsv.cvut.cz/ machacek/prednaskyNNK/NNK-11.pdf (January, 2018)

14. http://cze.sika.com/dms/getdocument.get/b1f6b60b-623c-33d9-8ac7ddfd79d1b207/Prohl.Sika\%20Tack\%20Panel.pdf (January, 2018)

15. ČSN 732577 (1981)

16. ČSN EN 1465 (2009)

17. P. Liška, J. Šlanhof, B. Nečasová, Adv. Mat. Res. 1041, 191-194 (2014)

18. P. Liška, J. Šlanhof, B. Nečasová, B. Kovářová, Adv. Mat.s Res. 824, 50-59 (2016)

19. ČSN EN 1990 (2004) 